KEYWORDS

Middle class

Economic conditions

Social conditions

Economic indicators

Statistical data

Households

Employment

Income

Latin America

Rolando Franco

ILPES/ECLAC consultant

- rolando.franco.diaz@gmail.com

Martín Hopenhayn

Director of the ECLAC Social

Development Division

. martin.hopenhayn@cepal.org

Arturo León

ECLAC consultant

- aleon@vtr.net
CEPAL REVIEW 103 APRIL 2011

\section{The growing and changing} middle class in Latin America:

\section{an update}

\author{
Rolando Franco, Martín Hopenhayn and Arturo León
}

$\mathrm{T}$

his paper employs a two-dimensional definition of the middle class that combines the occupation of the main household income provider (manual or non-manual) with family income as a proxy for consumption. This makes it possible to explore "objective" changes in the Latin American middle class between 1990 and 2007. "Subjective" changes in class values, aspirations and identity, among other things, are also analysed. The most salient findings are the growth of the middle class in both relative and absolute terms, the increase in education across the board (overshadowed by the devaluation of its relative importance for income generation) and the declining relevance of the distinction between manual and low-level non-manual occupations as an income determinant. The heterogeneity of the middle strata is brought to light in both vertical and horizontal sections for different types of risks and levels of well-being characteristic of households in each segment. 


\section{I}

\section{Introduction}

This article analyses the major changes that have occurred over the past two decades in the size of the Latin American middle class and in its composition and profiles. It also seeks to explore how these changes have altered patterns of class values, aspirations and identity in the societies of Latin America.

The growth of the middle strata is not something peculiar to the region but forms part of a global trend. Thus, the World Bank (2006) calculated that there were 1.3 billion middle-class people in the world, many of them in countries such as China and India. Goldman Sachs has highlighted the unprecedented growth in the number of people with middle-class incomes, an expansion that is put at 70 million a year, implying a total of some
2 billion people by 2030 , or about $30 \%$ of the world's population (Wilson and Dragusanu, 2008, p. 3).

With the universal character of the phenomenon thus established, this paper will now analyse the specific processes that the expansion of the middle classes has involved in a large group of Latin American countries. The information covers 10 countries accounting for $80 \%$ of the region's population. The book this article is based on (Franco, Hopenhayn and León, 2010) also includes national case studies of five countries containing $65 \%$ of the Latin American population. Before going into the data, however, it is necessary to look more closely at what is meant by the middle classes or strata, a concept that can often be elusive.

\section{II}

\section{What do we mean when we speak of the middle classes? Towards a two-dimensional definition}

Studying the middle class presents special difficulties, among which mention may be made of the following:

(i) The plurality or absence of definitions, resulting in attributes being ascribed to the wrong groups.

(ii) Conceptual hyperbole, i.e., the extension of observations made on a small and unrepresentative group to a body of people that is difficult to define.

(iii) Amalgamation, i.e., the use of attributes from different groups to create an ideal type of middle class (Escobar and Pedraza, 2010).

This study tries to deal with these risks by using an approach that employs objective dimensions such as occupation, income, education and consumption, while at the same time exploring subjective aspects such as values and aspirations, or people's adoption of particular lifestyles and mechanisms to establish some "distinction" (in the sense of distinguishing themselves, setting themselves apart) from other social strata. The belief is that using both perspectives permits a fuller and more complete approach to the object of study, namely the middle classes in Latin America today.
In the first instance, a comparative analysis is carried out between countries to capture changes arising over a fairly long period (1990-2007), using information from household surveys that reveals the size and characteristics of these strata. It must be warned that this choice of information source constrains the methodological options available, as will be seen further on.

Occupation has traditionally been viewed as the most vital dimension when it comes to capturing differences within society. It is upon this dimension that the leading studies and theories of social stratification are based. While the highest group is composed of employers and rentiers, the rest of the population is divided between those doing manual jobs and those carrying out non-manual or "white-collar" activities. This implies "intellectual" work, usually with stability of employment and a degree of material prosperity. The link between occupation type and income level is now weaker than formerly, however.

In many studies, consequently, it has been deemed better to use income to identify strata. Thus, the middle 
class has been defined by identifying it with the intermediate deciles of the distribution or, alternatively, by establishing fixed values around the median. The limitation of this procedure is that it cannot be used to identify differences in the size of the middle class when different countries are analysed. ${ }^{1}$ This does become possible when occupation (manual, non-manual) is used to differentiate between middle and lower strata. In this case, the relative size of the middle class differs substantially between countries in accordance with their development levels, including the degree of urbanization, productive differentiation, tertiarization of employment and the educational level of the population, among other factors. ${ }^{2}$ It should also be borne in mind that delimiting social groups on the basis of income alone is complicated by problems of data reliability in the surveys themselves and the great variability of employment situations in a given segment of the income distribution.

Given the advantages and limitations of using these variables on their own to define classes, this study has opted to combine two of them in a construct that has the following characteristics:

(i) Occupation is still considered relevant to the objective sought, but income is believed to be important as well, not just because it can be used to fix the economic level of each stratum, but because it is a proxy for consumption capacity and access to well-being for households. ${ }^{3}$ Table 1 sets out the terminology and empirical strategy used to delimit the middle social strata (MSs) within the population at large.

TABLE 1

Income strata

\begin{tabular}{lccc}
\hline & \multicolumn{3}{c}{ Stratum } \\
\cline { 2 - 4 } Occupational stratum & High & Middle & Low \\
\hline High & & MSS & \\
Middle & & MSS & MSs \\
Low & & MSs & \\
\hline
\end{tabular}

\footnotetext{
1 Differences obviously are identified when the strata are delimited using certain fixed limits or values or particular income brackets in the personal or family income distribution.

2 The manual stratum encompasses people working in agriculture, forestry and fisheries (Major Group 6 of the International Standard Classification of Occupations (ISCO 88)).

3 The clearest case is access to home mortgages. Banks and financial institutions grant these loans not just by evaluating the financial capacity of the applicant or holder of the loan, but on the basis of family income.
}

(ii) Family income and occupation are connected by the main household income recipient (MHIR), i.e., the family member (not necessarily the household head) receiving the largest monetary income, which may come from wage-paying work or selfemployment, capital (rents, profits and dividends) or transfers (retirement and other pensions, social programme transfers, remittances from abroad or from other households). Thus, some MHIRs are inactive but receive rents, a pension or income from transfers unrelated to employment.

(iii) Unlike studies of social stratification and mobility, this one takes the "household" and not the individual as the unit of analysis, which makes it possible to address issues such as family size, class "homogamy", family income composition (according to the number of active members in the household), etc. These issues cannot be studied when stratification is based solely on individuals' occupation, without reference to the household they are part of. Again by contrast with the usual practice in studies of this type, this one includes all households and not just those whose MHIR is in work. ${ }^{4}$

(iv) The boundaries of the middle class were established from the income distribution among MHIRs. The lower limit taken was four times the urban poverty line $e^{5}$ and the upper limit was the value for percentile 95 of this distribution. The middle income stratum was thus composed of households whose MHIRs declared income between the values indicated. It should be noted, however, that total family income (the sum of monetary resources brought in by all the members of the household) was taken as a stratification variable. ${ }^{6}$

\footnotetext{
4 These studies set out from the definition of occupational strata to analyse people's working careers during their active lives or compare the occupational position of parents and their active-age children. The unemployed are excluded for lack of information about their last job, as are the inactive (retirees, pensioners, rentiers). Some studies cover only a portion of the employed, such as men or people in work in certain age groups. This is the case when use is made of primary data based on ad hoc questionnaires applied to a sample of the population.

5 These poverty lines are estimated by ECLAC and vary from country to country. See ECLAC (2008a, Statistical annex, table 6).

6 These values were calculated for the latest year available in each country and then applied to the start year. Formerly, current localcurrency incomes from the surveys of each country and year were expressed in 2000 dollars at purchasing power parity so that comparisons could be made over time and between countries. Table 1 summarizes the income limits used and compares them with the median of the total household income distribution. Each main income recipient is associated with a family income constituted by the sum of the monetary incomes (from the three sources indicated above) of all the members of the household concerned.
} 
(v) The distinction between manual and non-manual occupations was made using the International Standard Classification of Occupations (ISCO) of the International Labour Organization, disaggregated at a one-digit level (major groups). This requires adjustment to make it consistent with the incorporation of income into the definition of the middle strata. ${ }^{7}$ Wage-earning and own-account MHIRs stating that they work in occupations belonging to Major Groups 1 to 5 of the ISCO form part of the middle occupational stratum; those working in occupations in Major Groups 6 to 9 (including group 0 , the armed forces) are in the low stratum. ${ }^{8}$ The high stratum is composed of employers and rentiers (when the MHIR is inactive). The retired were deemed to be middle-stratum income recipients (see table 2 ).

(vi) Certain absolute income values were established (in real terms); these need to be maintained over time to ascertain the extent to which changes in income levels and distribution affect the absolute and relative size of the middle strata. We ruled out other alternatives used in recent studies where income is adopted as a criterion for delimiting strata, particularly those that base their structure on certain intermediate deciles of the income distribution (Solimano, 2008) or take some income distribution parameter (the median, for example) and define the middle stratum as all households above and below certain proportions of the value of this parameter, e.g., between 0.75 and 1.25 times the median of the per capita household income distribution (Birdsall, Graham and Pettinato, 2000). Although these approaches do capture changes in the absolute size of the stratum, they cannot record changes in its relative size (based, by definition, on fixed percentiles), or can only record those resulting from changes in income distribution around the median. These variations

\footnotetext{
${ }^{7}$ Many of the classifications used in national surveys in the start year were adapted from ISCO 68, while those in the end year were generally from Isco 88. In some countries, however, the classification of the active population by occupations and trades bears no resemblance to the ILo recommendations, the household survey in Argentina being an example.

${ }^{8}$ Workers in non-manual occupations include members of the branches of the State; managerial staff in public administration; company directors and managers; professionals, scientists and intellectuals and intermediate-level technical and professional workers; office workers and skilled services workers; and salespeople. Workers in manual occupations include farmers and agricultural and fishery workers; operators, artisans, mechanics and installers; unskilled sales and services workers; and labourers.
}

TABLE 2

\section{Criteria used to delimit occupational strata}

\begin{tabular}{|c|c|c|c|}
\hline \multirow{2}{*}{ Main income recipient } & \multicolumn{3}{|c|}{ Occupational stratum } \\
\hline & High & Middle & Low \\
\hline In work & & & \\
\hline Employers & $\mathrm{X}$ & & \\
\hline $\begin{array}{l}\text { Own-account workers } \\
\text { in non-manual occupations }{ }^{\mathrm{a}} \\
\text { in manual occupations }^{\mathrm{b}}\end{array}$ & & $\mathrm{x}$ & $\mathrm{x}$ \\
\hline $\begin{array}{l}\text { Public- and private-sector wage workers } \\
\text { in non-manual occupations }{ }^{\mathrm{a}} \\
\text { in manual occupations }^{\mathrm{b}}\end{array}$ & & $\mathrm{x}$ & $\mathrm{x}$ \\
\hline
\end{tabular}

Not in work

\section{Rentiers}

Retirees $\mathrm{x}$

Other inactive ${ }^{c}$

$\mathrm{X}$

Source: prepared by the authors.

a Major Groups 1 to 5 of the International Labour Organization (ILO) International Standard Classification of Occupations (ISCO 88).

b Major Groups 6 to 9 and Group 0 of the ILO International Standard Classification of Occupations (ISCO 88).

c Includes main household income recipients (MHIRs) with income from remittances, cash transfers from social programmes and other non-work income.

are fairly small, since income distribution in the region's countries has not altered greatly, particularly where the intermediate deciles are concerned. From 1990 to 2006, the income share of households in deciles 5 to 9 registered absolute changes of 1 to 4 percentage points in 9 of the 10 countries selected. The exception is Honduras, where there was a rise of 6 points (see ECLAC, 2008a, Statistical annex, table 12).

(vii) Total family income was used as a proxy for consumption capacity. This is a departure from the usual practice in poverty studies, most of which go by per capita household income.

(viii) The size of the middle class is not fixed but varies by the level of development in each country. The value of four times the urban poverty line as a proportion of the median of the distribution (see the last column of table 3 ) is closely related to the level of per capita income, ${ }^{9}$ to the percentage of

\footnotetext{
9 The higher per capita income is, the lower the ratio between four poverty lines (PL) and the median of the household income distribution.
} 
TABLE 3

Latin America (10 countries, various periods): values used

to classify households by income stratum

(Monthly wages in 2000 dollars at purchasing power parity)

\begin{tabular}{lccccc}
\hline Country & Period & 4PL per capita & Percentile $^{\mathrm{a}} 5^{\mathrm{b}}$ & 4PL / Median $^{\mathrm{c}}$ & 4PL / Median $^{\mathrm{d}}$ \\
\hline Argentina & $1990-2006$ & 976 & 4522 & 0.65 & 0.62 \\
Brazil & $1990-2007$ & 792 & 3397 & 1.39 & 0.96 \\
Chile & $1990-2006$ & 552 & 3569 & 0.88 & 0.52 \\
Colombia & $1991-2005$ & 969 & 3259 & 1.10 & 1.09 \\
Costa Rica & $1990-2007$ & 687 & 2950 & 0.84 & 0.63 \\
Honduras & $1990-2007$ & 790 & 1560 & 2.51 & 1.73 \\
Mexico & $1989-2006$ & 861 & 2850 & 0.93 & 0.88 \\
Panama & $1991-2007$ & 514 & 2254 & 1.18 & 0.65 \\
Peru & $1997-2003$ & 681 & 1674 & 0.88 & 1.30 \\
Dominican Republic & $1997-2007$ & 887 & 2241 & 1.11 \\
\hline
\end{tabular}

Source: Economic Commission for Latin America and the Caribbean (ECLAC), on the basis of special tabulations of household surveys from the countries concerned.

a Four times the urban poverty line in each country.

Percentile 95 of the income distribution for main household income recipients.

Four poverty lines as a fraction of the median of the total household income distribution in the start year.

Four poverty lines as a fraction of the median of the total household income distribution in the end year.

Greater Buenos Aires.

people living in urban areas, to the level of education in the population, to average household income and consumption, to the wage employment rate and to the diversification of countries' production structure, which is accompanied by growth in the tertiary sector and particularly in the non-manual or "white collar" jobs typical of the middle-class. In addition, the relative position of the value delimiting the middle stratum from the low-income stratum (third and fourth columns of table 3 ) changes between the start and end years in accordance with the variation in countries' economic growth. This shows that part of the increase in the middle social strata in the period examined came from rising income and consumption in the low-income stratum. In sum, the procedure for determining income boundaries allows comparisons to be drawn between countries and highlights the effect of the rising incomes and distributive changes of the past 15 years on social stratification in the region.

\section{III}

\section{Current features and changing circumstances in the middle class}

The changes that occurred in the period under review (1990-2006/2007) originated in the expansion of nonmanual employment and the growth in household's consumption capacity, as will now be shown.

\section{Size and evolution of the middle stratum from an occupational perspective}

Non-manual employment has been expanding since the late 1980s. In two countries, Argentina and Chile, just over half of all households belong to the middle stratum. ${ }^{10}$ In Brazil, $46 \%$ are in this stratum. In three of the other countries considered the proportion is about $40 \%$, while in a further three it is of the order of $30 \%$. In the remainder, a quarter of households are in this stratum.

\footnotetext{
10 Although the reference is to Greater Buenos Aires, this information is very likely to be nationally representative given the high degree of urbanization in Argentina (over $85 \%$ of the population live in urban areas).
} 


\section{Incorporation into the middle stratum via growth in consumption capacity}

The countries analysed saw substantial absolute growth in per capita gross domestic product (GDP) within the space of a generation, increasing the income (and thus consumption) of households in the middle and low strata (see table 4). ${ }^{11}$ The result was an upward shift in the distribution by income bracket of households in the middle and low occupational strata from the under-US \$ 5,000 a year bracket (calculated per family at purchasing power parity) towards the intermediate bracket (between US\$ 5,000 and US\$ 15,000 a year) and even the upper bracket (over US\$ 15,000). ${ }^{12}$ This shift was recorded in almost all the countries (see table 5). There was consequently a large increase in the consumption capacity of households in the middle and low strata, but without significant changes in the (highly concentrated) income distribution. ${ }^{13}$ Because of this, there

\footnotetext{
11 Those main household income recipients (MHIRs) who were 30 in 1990 are now around 50. Thus, income changes are characterized by mobility within the space of a generation.

12 This shift, which is very important from a social stratification perspective, does not show up in analyses of income distribution between household deciles or quintiles.

${ }^{13}$ In Brazil, Colombia, Costa Rica and Peru, the income share of the $50 \%$ of households above the poorest $40 \%$ fell by between 1.5 and 4.5
}

were groups of manual workers who attained to incomes even higher than those of non-manual wage workers, whose remuneration failed to keep pace with theirs or even declined during the period under review.

This favourable change in low-stratum incomes, which was very marked in Brazil, Chile and Panama, was reinforced by the growth of consumer and mortgage lending and by the substantial fall in the relative (and in many cases absolute) prices of the goods consumed by the middle strata. Household purchasing power was also lifted by both the reduction in the number of people per household and the fall in the economic dependency rate, as analysed below. ${ }^{14}$ At the same time, the decline in the relative prices of mass consumption "durable" goods is partly the effect of comparison with increasingly costly health care and education, which are taking up a growing share of family budgets in the middle strata. This being so, there are limits on the ability of people in the low stratum to attain to middle-stratum consumption patterns, and social divides are often manifested in the affordability or otherwise of private health care and education.

percentage points. In the other countries, the share of this segment rose by between 1.5 and 2.5 percentage points. The increase in Honduras was 6 percentage points (ECLAC, 2008a, Statistical annex, table 12). 14 Treating the household as the unit of analysis provides a better picture of these phenomena than analyses centred on individuals.

TABLE 4

Latin America (10 countries, various periods): level and growth of per capita GDP

(Monthly wages in 2000 dollars at purchasing power parity)

\begin{tabular}{lcccccc}
\hline Country & Period $^{\mathrm{a}}$ & Start year & End year & Absolute increase & Percentage increase & Annual growth rate \\
\hline Argentina & $1990-2006$ & 8781 & 13652 & 4871 & 55.5 & 2.8 \\
Brazil & $1990-2007$ & 6480 & 8152 & 1672 & 25.8 & 1.4 \\
Chile & $1990-2006$ & 5744 & 10939 & 5194 & 90.4 & 4.1 \\
Colombia & $1991-2005$ & 5590 & 6536 & 945 & 16.9 & 1.1 \\
Costa Rica & $1990-2007$ & 6268 & 9067 & 2799 & 44.6 & 2.2 \\
Honduras & $1990-2007$ & 2744 & 3312 & 568 & 20.7 & 1.1 \\
Mexico & $1989-2006$ & 7517 & 9967 & 2450 & 32.6 & 1.7 \\
Panama & $1991-2007$ & 4842 & 7917 & 3075 & 63.5 & 3.1 \\
Peru & $1997-2003$ & 4812 & 4942 & 130 & 52.1 & 0.4 \\
Dominican Republic & $1997-2007$ & 5359 & 8149 & 2790 & & 4.3 \\
Argentina & $1990-1999$ & 8781 & 12322 & 3541 & 40.3 & -18.0 \\
Argentina & $1999-2002$ & 12322 & 10098 & -2224 & 35.2 & -6.4 \\
Argentina & $2002-2006$ & 10098 & 13652 & 3555 & & 10.6
\end{tabular}

Source: prepared by the authors on the basis of information from World Bank databases.

GDP: gross domestic product.

a Annual income based on monthly wages in 2000 dollars at purchasing power parity. 
TABLE 5

Latin America (10 countries, various years): distribution of households by family income bracket ${ }^{a}$ and occupational stratum ${ }^{b}$

\begin{tabular}{|c|c|c|c|c|c|c|}
\hline & Middle stratum & $\begin{array}{l}\text { Low stratum } \\
\text { (Year) }\end{array}$ & Total & Middle stratum & $\begin{array}{l}\text { Low stratum } \\
\text { (Year) }\end{array}$ & Total \\
\hline Argentina ${ }^{c}$ & & (1990) & & & (2006) & \\
\hline Up to 5000 & 5 & 15 & 11 & 3 & 9 & 6 \\
\hline 5001 to 15000 & 33 & 34 & 32 & 31 & 37 & 32 \\
\hline Over 15000 & 63 & 51 & 58 & 66 & 54 & 62 \\
\hline Brazil & & (1990) & & & (2007) & \\
\hline Up to 5000 & 30 & 50 & 40 & 14 & 33 & 23 \\
\hline 5001 to 15000 & 35 & 36 & 35 & 43 & 47 & 44 \\
\hline Over 15000 & 35 & 14 & 25 & 43 & 20 & 33 \\
\hline Chile & & (1990) & & & (2006) & \\
\hline Up to 5000 & 23 & 41 & 32 & 12 & 20 & 15 \\
\hline 5001 to 15000 & 43 & 45 & 43 & 36 & 52 & 42 \\
\hline Over 15000 & 35 & 14 & 25 & 53 & 28 & 43 \\
\hline Colombia & & (1991) & & & (2005) & \\
\hline Up to 5000 & 16 & 20 & 18 & 10 & 26 & 20 \\
\hline 5001 to 15000 & 39 & 52 & 47 & 33 & 51 & 44 \\
\hline Over 15000 & 45 & 28 & 35 & 58 & 23 & 36 \\
\hline Costa Rica & & (1990) & & & (2007) & \\
\hline Up to 5000 & 10 & 26 & 19 & 9 & 21 & 15 \\
\hline 5001 to 15000 & 43 & 54 & 49 & 33 & 51 & 42 \\
\hline Over 15000 & 46 & 21 & 33 & 58 & 28 & 43 \\
\hline Honduras & & (1990) & & & (2007) & \\
\hline Up to 5000 & 27 & 69 & 60 & 20 & 58 & 47 \\
\hline 5001 to 15000 & 43 & 27 & 30 & 43 & 34 & 36 \\
\hline Over 15000 & 30 & 5 & 10 & 37 & 9 & 17 \\
\hline Mexico & & (1989) & & & (2006) & \\
\hline Up to 5000 & 11 & 27 & 21 & 8 & 20 & 14 \\
\hline 5001 to 15000 & 47 & 53 & 50 & 40 & 55 & 47 \\
\hline Over 15000 & 43 & 20 & 30 & 52 & 25 & 38 \\
\hline Panama & & (1991) & & & (2007) & \\
\hline Up to 5000 & 17 & 54 & 39 & 12 & 37 & 26 \\
\hline 5001 to 15000 & 45 & 36 & 40 & 44 & 44 & 43 \\
\hline Over 15000 & 38 & 10 & 21 & 43 & 19 & 31 \\
\hline Peru & & (1997) & & & (2003) & \\
\hline Up to 5000 & 14 & 48 & 37 & 15 & 52 & 41 \\
\hline 5001 to 15000 & 48 & 41 & 43 & 50 & 40 & 43 \\
\hline Over 15000 & 38 & 11 & 20 & 36 & 8 & 17 \\
\hline Dominican Republic & & (1997) & & & (2007) & \\
\hline Up to 5000 & 6 & 19 & 15 & 18 & 37 & 30 \\
\hline 5001 to 15000 & 36 & 49 & 45 & 39 & 36 & 36 \\
\hline Over 15000 & 58 & 32 & 40 & 43 & 27 & 35 \\
\hline
\end{tabular}

Source: Economic Commission for Latin America and the Caribbean (ECLAC), on the basis of special tabulations of household surveys from the countries concerned.

a The income brackets are for annual income based on monthly wages in 2000 dollars at purchasing power parity.

b Some columns do not add up to $100 \%$ because of rounding.

c Greater Buenos Aires. 


\section{The heterogeneity of the middle strata}

\section{(a) Segmentation by definition}

According to the definition adopted for the middle strata, three subsets of households can be identified. They are:

(i) The "consistent" middle class, consisting of middleclass households whose main income provider (MHIR) works in a non-manual occupation and where total family income (the sum of all income provided by all household members whether deriving from work, capital or transfers) ranges between the equivalent of four poverty lines (the lower limit) and the value of percentile 95 of the distribution (the upper limit). ${ }^{15}$

(ii) The "inconsistent" middle class, comprising households whose MHIR works in a manual occupation, even though the family's total income is of a middle-class level.

(iii) The "precarious" middle class. A large percentage of non-manual wage earners are in unstable employment with very low incomes and often with no contract or social security coverage, and thus are in very much the same situation as manual wage earners and lowskilled own-account workers. Some households in the middle stratum even live in absolute poverty. In the countries with the lowest poverty indices, between $5 \%$ and $9 \%$ of households in the middle occupational stratum were in this situation in 20062007. The proportion was about a sixth in Brazil and Mexico, between $20 \%$ and $30 \%$ in Colombia, the Dominican Republic and Peru, and as high as $38 \%$ in Honduras. ${ }^{16}$

\section{(b) Hierarchical segmentation}

Classifying the population by occupation and sector or category of employment gives an idea of the relative size of the two middle substrata (upper and lower).

15 Total family income is different from per capita household income, i.e., total income divided by the number of household members, which is what poverty studies use. Likewise, the unit of analysis is the household and not one of the individuals composing it, such as the household head, as is the case with social mobility studies (see León, Espíndola and Sembler, 2010).

16 On the incidence of poverty, see ECLAC, Social Panorama of Latin America, various editions. This is an indicator whose calculations take account of the number of people in each household, and it includes the monetary income of all working members and income received by inactive members from non-work sources. However, over two thirds of the total income of households in each occupational stratum (the middle stratum in this case) is brought in by the main income recipient, so that the value of the poverty indicator largely captures the low incomes of working people in the lower middle stratum.
Although it is not possible to completely homogenize the occupational classifications used in 1990 with the current ones, it is possible to estimate what the relative size of these two strata would be now and to highlight the diversity of occupations in the middle occupational stratum.

In 7 of the 10 countries considered, the lower middle stratum contains between two thirds and over three quarters of all households in the whole middle stratum. This is the "gateway" for the middle class, to which a secondary or technical school credential provides access. This lower middle stratum is also the "border zone" with the low stratum, at least in income terms. It is among lower-level non-manual occupations that it is most common to see individual trajectories of upward mobility (by way of employment opportunities) and downward mobility (resulting from recessions and crises or other contingencies) (Kessler and Espinoza, 2007).

\section{(c) Horizontal segmentation}

The main types of horizontal segmentation that can be identified in the middle class are between public- and private-sector employment and between wage and ownaccount employment. ${ }^{17}$

\section{- Public- or private-sector employment}

A number of authors have argued that the growth of the middle class in the region took place because of the expansion of the State and the rise in public-sector employment. This particular middle sector is also presented as the embodiment of a culture that has underpinned the outlook of the whole "class", based on a concern with education and a particular lifestyle, and is said to have been affected by reforms that have reduced the role of the State and thereby diminished public-sector employment (Klein and Tokman, 2000; Torche, 2006).

The present study has not been able to confirm this hypothesis. In only a few of the selected countries, admittedly, has it been possible to compare the scale of public-sector employment in 1990 and a recent year. In four cases (Argentina, Brazil, Chile and Mexico), the information for the base year did not discriminate between public- and private-sector employees. In cases where it was possible to make this comparison for main income recipients and for the employed population as a whole, middle-class public-sector employment was found to have held fairly steady in Honduras, Peru and

17 The self-employed are those not working for a wage or salary. They include both employers and own-account workers who do not have employees of their own. The distinction between wage earners and non-wage earners excludes employers (however many workers they employ), who form part of the high stratum according to the definition of occupational strata used. 
Colombia, to have fallen in Costa Rica and Panama and to have grown only in the Dominican Republic (see tables 6 and 7).

In the cases of Argentina, Brazil and Chile there are data for the end year of the series used, plus other information indicative of the trend. For Brazil there is information from administrative records indicating that public-sector employment held steady as a share of total employment during the 1990s, although its distribution changed, since it decreased at the federal and state levels and expanded at the municipal level (Pessoa de Carvalho Filho, Eneuton Dornellas 2002). It can thus be stated with some confidence that publicsector employment in the country continued at around $24 \%$ of the total. In Chile, the employment surveys of the National Institute of Statistics (INE) indicate that public-sector employment increased as a share of the total (from $6.9 \%$ to $7.4 \%$ ) between 1990 and 2000,

TABLE 6

Latin America (10 countries): distribution of main household income recipients, by occupational category, around 1990 and 2007

\begin{tabular}{|c|c|c|c|c|c|c|c|c|c|c|}
\hline \multirow{2}{*}{ Middle stratum ${ }^{\mathrm{b}}$} & \multicolumn{2}{|c|}{ Argentina $^{a}$} & \multicolumn{2}{|c|}{ Brazil } & \multicolumn{2}{|c|}{ Chile } & \multicolumn{2}{|c|}{ Colombia } & \multicolumn{2}{|c|}{ Costa Rica } \\
\hline & 1990 & 2006 & 1990 & 2007 & 1990 & 2006 & 1991 & 2005 & 1990 & 2007 \\
\hline Public employee & $\ldots$ & 20 & $\ldots$ & 24 & $\ldots$ & 14 & 16 & 18 & 40 & 31 \\
\hline Private employee & 74 & 58 & 66 & 53 & 66 & 63 & 39 & 42 & 40 & 58 \\
\hline Own-account & 26 & 22 & 34 & 24 & 34 & 23 & 44 & 40 & 20 & 11 \\
\hline Total & 100 & 100 & 100 & 100 & 100 & 100 & 100 & 100 & 100 & 100 \\
\hline \multicolumn{11}{|l|}{ Total $^{c}$} \\
\hline Public employee & $\ldots$ & 12 & $\ldots$ & 13 & $\ldots$ & 11 & 8 & 8 & 19 & 16 \\
\hline Private employee & 66 & 62 & 63 & 52 & 69 & 63 & 46 & 42 & 46 & 56 \\
\hline Own-account & 26 & 21 & 29 & 30 & 27 & 22 & 41 & 42 & 27 & 19 \\
\hline Employer & 8 & 5 & 8 & 6 & 4 & 4 & 4 & 8 & 9 & 10 \\
\hline Total & 100 & 100 & 100 & 100 & 100 & 100 & 100 & 100 & 100 & 100 \\
\hline \multirow{2}{*}{ Middle stratum ${ }^{\mathrm{b}}$} & \multicolumn{2}{|c|}{ Honduras } & \multicolumn{2}{|c|}{ Mexico } & \multicolumn{2}{|c|}{ Panama } & \multicolumn{2}{|c|}{ Peru } & \multicolumn{2}{|c|}{$\begin{array}{c}\text { Dominican } \\
\text { Republic }\end{array}$} \\
\hline & 1990 & 2007 & 1989 & 2006 & 1991 & 2007 & 1997 & 2003 & 1997 & 2007 \\
\hline Public employee & 24 & 24 & $\ldots$ & $\ldots$ & 47 & 37 & 26 & 29 & 20 & 23 \\
\hline Private employee & 32 & 44 & 73 & 70 & 39 & 49 & 40 & 40 & 43 & 44 \\
\hline Own-account & 44 & 32 & 27 & 30 & 14 & 14 & 33 & 31 & 38 & 33 \\
\hline Total & 100 & 100 & 100 & 100 & 100 & 100 & 100 & 100 & 100 & 100 \\
\hline \multicolumn{11}{|l|}{ Total $^{c}$} \\
\hline Public employee & 9 & 9 & $\ldots$ & $\ldots$ & 25 & 18 & 10 & 11 & 12 & 12 \\
\hline Private employee & 36 & 45 & 65 & 69 & 35 & 47 & 33 & 33 & 37 & 34 \\
\hline Own-account & 53 & 43 & 30 & 25 & 34 & 30 & 47 & 47 & 45 & 48 \\
\hline Employer & 2 & 3 & 5 & 6 & 5 & 5 & 10 & 9 & 6 & 6 \\
\hline Total & 100 & 100 & 100 & 100 & 100 & 100 & 100 & 100 & 100 & 100 \\
\hline
\end{tabular}

Source: Economic Commission for Latin America and the Caribbean (ECLAC), on the basis of special tabulations of household surveys from the countries concerned.

a Greater Buenos Aires.

b Main income recipients in the middle occupational stratum. Employers belong to the high occupational stratum.

c All main income recipients (from the high, middle and low occupational strata).

...: The missing data are not separately available. Public-sector employees are included in the private-sector employees category in these cases. 
TABLE 7

Latin America (10 countries): distribution of all persons in employment, by occupational category, around 1990 and 2007

\begin{tabular}{|c|c|c|c|c|c|c|c|c|c|c|}
\hline \multirow{2}{*}{ Middle stratum ${ }^{b}$} & \multicolumn{2}{|c|}{ Argentina $^{\mathrm{a}}$} & \multicolumn{2}{|c|}{ Brazil } & \multicolumn{2}{|c|}{ Chile } & \multicolumn{2}{|c|}{ Colombia } & \multicolumn{2}{|c|}{ Costa Rica } \\
\hline & 1990 & 2006 & 1990 & 2007 & 1990 & 2006 & 1991 & 2005 & 1990 & 2007 \\
\hline Public employee & $\ldots$ & 18 & $\ldots$ & 19 & $\ldots$ & 13 & 13 & 13 & 32 & 27 \\
\hline Private employee & 74 & 61 & 71 & 56 & 71 & 65 & 51 & 46 & 46 & 60 \\
\hline Own-account & 25 & 20 & 28 & 24 & 29 & 21 & 36 & 40 & 21 & 13 \\
\hline Employer & 1 & 1 & 1 & 1 & 0 & 0 & 1 & 1 & 1 & 1 \\
\hline Total & 100 & 100 & 100 & 100 & 100 & 100 & 100 & 100 & 100 & 100 \\
\hline \multicolumn{11}{|l|}{ Total $^{\mathrm{c}}$} \\
\hline Public employee & $\ldots$ & 12 & $\ldots$ & 12 & $\ldots$ & 10 & 7 & 6 & 16 & 14 \\
\hline Private employee & 70 & 65 & 66 & 54 & 73 & 66 & 53 & 45 & 52 & 60 \\
\hline Own-account & 25 & 19 & 29 & 31 & 24 & 21 & 38 & 44 & 26 & 18 \\
\hline Employer & 5 & 4 & 5 & 4 & 3 & 3 & 3 & 5 & 6 & 7 \\
\hline Total & 100 & 100 & 100 & 100 & 100 & 100 & 100 & 100 & 100 & 100 \\
\hline \multirow{2}{*}{ Middle stratum ${ }^{b}$} & \multicolumn{2}{|c|}{ Honduras } & \multicolumn{2}{|c|}{ Mexico } & \multicolumn{2}{|c|}{ Panama } & \multicolumn{2}{|c|}{ Peru } & \multicolumn{2}{|c|}{$\begin{array}{l}\text { Dominican } \\
\text { Republic }\end{array}$} \\
\hline & 1990 & 2007 & 1989 & 2006 & 1991 & 2007 & 1997 & 2003 & 1997 & 2007 \\
\hline Public employee & 19 & 19 & $\ldots$ & $\ldots$ & 40 & 30 & 20 & 20 & 17 & 20 \\
\hline Private employee & 38 & 44 & 75 & 69 & 46 & 54 & 43 & 42 & 48 & 45 \\
\hline Own-account & 43 & 36 & 25 & 30 & 14 & 17 & 36 & 37 & 34 & 34 \\
\hline Employer & 0 & 1 & 0 & 1 & 0 & 0 & 1 & 1 & 0 & 1 \\
\hline Total & 100 & 100 & 100 & 100 & 100 & 100 & 100 & 100 & 100 & 100 \\
\hline \multicolumn{11}{|l|}{ Total $^{\mathrm{c}}$} \\
\hline Public employee & 7 & 7 & $\ldots$ & $\ldots$ & 23 & 15 & 9 & 8 & 11 & 12 \\
\hline Private employee & 38 & 44 & 67 & 68 & 41 & 50 & 35 & 33 & 45 & 37 \\
\hline Own-account & 54 & 46 & 30 & 28 & 33 & 31 & 51 & 55 & 40 & 47 \\
\hline Employer & 1 & 2 & 3 & 4 & 3 & 3 & 5 & 5 & 4 & 4 \\
\hline Total & 100 & 100 & 100 & 100 & 100 & 100 & 100 & 100 & 100 & 100 \\
\hline
\end{tabular}

Source: Economic Commission for Latin America and the Caribbean (ECLAC), on the basis of special tabulations of household surveys from the countries concerned.

a Greater Buenos Aires.

b All those employed in households in the middle occupational stratum.

c All those employed in households in the high, middle and low occupational strata.

...: The missing data are not separately available. Public-sector employees are included in the private-sector employees category in these cases.

implying a slight drop in its share of middle-sector employment, from 22\% to 20\% (León and Martínez, 2007; Torche and Wormald, 2007). ${ }^{18}$ Since the middle of the last decade, however, public-sector employment

18 The data on Chile were obtained from the National Socio-economic Survey (CASEN 1990 and 2006), which has advantages from the standpoint of income measurement. The employment surveys of the National Institute of Statistics (INE), on the other hand, allow measurements of the level and structure of employment to be compared over time. has increased by some $35 \%$, outstripping the growth in private-sector wage employment (22\%) and own-account employment (20\%) (Méndez, 2009). ${ }^{19}$

In Argentina, the total public-sector share of employment increased slightly from 1999 to 2006 (from $15.5 \%$ to $16.2 \%$ ), after peaking in $2002(21.7 \%)$. This figure includes those employed under government job

19 The percentage increases in the three categories are for the 19962006 period. See Méndez (2009, table 5). 
creation programmes. ${ }^{20}$ In Mexico, the data for 1994, 1996, 1998 and 2002 show a slight drop and then a recovery, so that the figure ranged between $11 \%$ and $12 \%$ over the period (ECLAC, 2008a). ${ }^{21}$

To sum up, the public-sector share of middle-class employment did not fall substantially in these countries. This tells us nothing about whether the symbolic and socio-economic status of such jobs may have declined. However, the pay of public-sector employees has increased by more than that of private-sector wage earners in most of the countries in recent years (ECLAC, 2008a). ${ }^{22}$

- Wage earners and the self-employed

There was a clearer restructuring trend in privatesector occupations. Wage employment increased and selfemployment or own-account working declined. This seems to run counter to the idea of a middle class increasingly composed of professionals and skilled technical workers operating independently on a self-employment basis or as small employers. In all the countries analysed except Mexico and Panama, self-employment lost ground in

20 The Heads of Household Programme began to be operated in early 2002 and created over 2 million jobs for the unemployed (figure published by the Ministry of Labour, Employment and Social Security, http://www.trabajo.gov.ar).

21 See eclac (2008a), Statistical annex, table 17.

22 See eClaC (2008a), Statistical annex, table 21. the middle sector. This was more marked among MHIRs than among the generality of people in employment in this stratum (see tables 6 and 7). ${ }^{23}$

The rise in female workforce participation was crucial to the growth of the middle stratum. This participation grew substantially between 1990 and 2007 . In 7 of the 10 countries, women's economic activity rate rose by between 6 and 14 percentage points. The increase was greatest in Brazil, Chile, Costa Rica and Mexico, the countries where the middle stratum grew most strongly. ${ }^{24}$ The growth of female participation was particularly strong among more highly educated women (ECLAC, 2008a), who went into commerce and services occupations (office workers, secretaries, shop and supermarket employees and health service workers). Participation rates also rose among women with higher education (professionals composing the upper middle stratum), but by less as they were already quite high by the early 1990s.

${ }^{23}$ Self-employment declined in the great majority of countries. There is no breakdown of the data by age group. If there were, it would be possible to observe whether the reduction in self-employment is also found among young people entering the labour market. Again, the occupational characteristics recorded are those of people's main job. People who are wage earners in their main job often work on a selfemployed basis in their secondary economic activity.

24 See eclac (2008a), Statistical annex, table 16.

\section{IV}

\section{The determinants of change}

\section{Size matters}

The real impact of growth on consumption patterns cannot be properly appreciated when the data are analysed in percentage terms. It comes out more clearly when absolute values are considered, together with the size and growth rate of the population, especially in urban centres or in particular areas of large cities.

The number of middle-class households grew by 56 million in the universe of 10 countries taken, representing $80 \%$ of the Latin American population. This implies a large expansion of the consumer market. In the region's largest country, Brazil, the number of people living in middle-stratum households rose from 23 million in 1990 to 61 million in 2007. The number of households in the middle stratum more than doubled from 9.3 million in 1990 to 20.8 million in 2007, and their share of all households rose from $36 \%$ to $46 \%$. In a similar period, the number of middle-class households in Chile grew by some 1.1 million, almost doubling the figure of 1.2 million estimated for the start year. In Argentina, while the proportion of middle-class households fell from $56 \%$ to $52 \%$, the absolute number increased by about half a million, which is actually more than the increase in the number of people (440 thousand), owing to the sharp decline in the size of households in this stratum. The large number and spatial concentration of middle-stratum households have created a demonstration effect in society at large, influencing consumption habits and consequently generating a widespread feeling of belonging to this stratum. 
The decline in the number of people per household was seen everywhere, albeit to varying degrees that depended on the fertility level in each country 15 years ago, socio-economic conditions and the cultural patterns characterizing the different social strata (ECLAC, 2004). In countries with larger households, the drop in the number of members in the early 1990s is probably explained mostly by falling fertility (Mexico and Honduras), while in those with lower fertility rates the reduction owes more to the rising proportion of single-person households and those consisting of childless couples (Argentina).

The dependency rate, which combines the effects of falling household size and a rising number of members in work, fell both in the middle stratum (from $2.7 \%$ to $2.1 \%$ ) and in the low one (from $2.8 \%$ to $2.4 \%$ ). A crucial role was played in this process both by the drop in fertility and by the rise in female workforce participation (especially among more educated women) and the change in family types. Brazil and Mexico are the two countries that registered the largest increase in the rate of female participation in economic activity during the period reviewed. This rate increased from $44 \%$ to $58 \%$ in Brazil and from $30 \%$ to $48 \%$ in Mexico. ${ }^{25}$

\section{The middle sectors are growing}

Taking the countries analysed as a whole, the number of middle-class households has been growing, as has the proportion of all households they represent. The exceptions are Argentina, where this share fell from 56\% to 52\%, and Colombia, where it held steady. The middle stratum is larger in more developed countries. Whereas it only includes 25\% of households in Honduras, the proportion in Argentina and Chile is around 50\%. In Chile, 40\% of households were middle-class in 1990, whereas 52\% are now. Another development of note is the increase in family incomes in lower-class households, defined as those whose MHIR works in a manual occupation. This has caused incomes in this sector of households to shift to a higher bracket, i.e., from the stratum where family incomes are US $\$ 5,000$ and under to the stratum where they are between US\$ 5,000 to US\$ 15,000 .

There has been a large increase in middle-income households. In Argentina, Chile and Panama this increase has largely come from improvements in households in the lower occupational stratum. In Brazil, Costa Rica, Honduras and Mexico, the increase in these households

25 See eclac (2008a, Statistical annex, table 16). was smaller but still significant, especially given the expansion in the total number of households in the middle social strata (see the last column of table 8 ).

It should be emphasized, however, that a fairly large proportion of all middle-stratum households have inadequate incomes. The figure for households in the middle social strata with low incomes is $51 \%$ in Brazil,

TABLE 8

Latin America (10 countries): households in the middle social strata, around 1990 and 2007

\begin{tabular}{|c|c|c|c|c|c|}
\hline \multirow[t]{2}{*}{ Country } & \multirow[t]{2}{*}{ Year } & $\begin{array}{c}\text { With } \\
\text { middle } \\
\text { incomes }\end{array}$ & $\begin{array}{l}\text { Middle } \\
\text { stratum } \\
\text { with low } \\
\text { incomes }\end{array}$ & $\begin{array}{l}\text { Middle } \\
\text { social } \\
\text { strata }\end{array}$ & \multirow{2}{*}{$\begin{array}{c}\begin{array}{c}\text { Total } \\
\text { households }\end{array} \\
\text { (thousands) }\end{array}$} \\
\hline & & \multicolumn{3}{|c|}{$\left(\right.$ percentages $\left.^{\mathrm{c}}\right)$} & \\
\hline \multirow[t]{2}{*}{ Argentina $^{\mathrm{d}}$} & 1990 & 25 & 42 & 67 & 2181 \\
\hline & 2006 & 54 & 20 & 74 & 3134 \\
\hline \multirow[t]{2}{*}{ Brazil } & 1990 & 24 & 22 & 46 & 15825 \\
\hline & 2007 & 26 & 27 & 53 & 33454 \\
\hline \multirow[t]{2}{*}{ Chile } & 1990 & 31 & 23 & 54 & 1702 \\
\hline & 2006 & 54 & 16 & 70 & 3645 \\
\hline \multirow[t]{2}{*}{ Colombia } & 1991 & 23 & 20 & 43 & 3012 \\
\hline & 2005 & 23 & 16 & 39 & 4674 \\
\hline \multirow[t]{2}{*}{ Costa Rica } & 1990 & 45 & 13 & 58 & 320 \\
\hline & 2007 & 50 & 12 & 62 & 834 \\
\hline \multirow[t]{2}{*}{ Honduras } & 1990 & 9 & 12 & 21 & 170 \\
\hline & 2007 & 11 & 17 & 28 & 544 \\
\hline \multirow[t]{2}{*}{ Mexico } & 1989 & 23 & 21 & 44 & 6940 \\
\hline & 2006 & 26 & 22 & 48 & 14160 \\
\hline \multirow[t]{2}{*}{ Panama } & 1991 & 39 & 12 & 51 & 260 \\
\hline & 2007 & 47 & 12 & 59 & 610 \\
\hline \multirow[t]{2}{*}{ Peru } & 1997 & 16 & 16 & 32 & 1665 \\
\hline & 2003 & 14 & 18 & 32 & 2248 \\
\hline Dominican & 1997 & 28 & 11 & 39 & 633 \\
\hline Republic & 2007 & 20 & 18 & 38 & 1081 \\
\hline
\end{tabular}

Source: Economic Commission for Latin America and the Caribbean (ECLAC), on the basis of special tabulations of household surveys from the countries concerned.

a Households where the income of the MHIR is greater than four times the per capita urban poverty line and less than the percentile 95 value.

b Households in the middle occupational stratum where the income of the MHIR is four times the per capita urban poverty line or less.

c Percentages of all households in the country.

d Greater Buenos Aires. 
while in Chile it fell from $43 \%$ to $23 \% .{ }^{26}$ A similar change occurred in Argentina, although the increase in the proportion of households belonging to the middle social strata was smaller than in Chile. In the other countries, these changes in the composition of the middle social strata were less substantial.

When the middle social strata are delimited using the combination of occupational category and income, the mass of such households is large, accounting for some $50 \%$ or even more of the total in Argentina, Brazil, Chile, Costa Rica, Mexico and Panama. These figures support the picture that emerges from different opinion polls and surveys, where a very high proportion of respondents claim to belong to the "middle class".

\section{Educational capital is increasing, but is being devalued}

Education levels have increased rapidly in the region over the past two decades. Rising enrolment and graduation rates at all levels have led to a very substantial change in the educational profile of the economically active population. Educational capital remains crucial for incorporation into the middle strata, whether in routine non-manual jobs, which require certification of the second cycle of intermediate or secondary education, or in occupations typical of the upper middle stratum, requiring a professional higher education qualification.

Completion of the secondary cycle is now becoming the rule for the new generations. In 1990, between 30\% and $40 \%$ of middle-class MHIRs had attained this level of education. Now, between $50 \%$ and $70 \%$ of MHIRs have completed it, depending on the country. In Argentina, $31 \%$ of MHIRs had formerly completed their technical education, whereas the figure now is $47 \%$. Meanwhile, the proportion of MHIRs with this level of education has risen from $28 \%$ to $48 \%$ in Brazil and from $41 \%$ to $57 \%$ in Chile. Likewise, $83 \%$ of middle-class young people have completed at least their secondary studies, and may have gone on to a higher educational level, by the time they enter the labour market.

This increase in education has also occurred among people working in low-stratum occupations, but only those with complete secondary education have a good chance of obtaining non-manual jobs. Those already in the labour market who have not completed secondary

\footnotetext{
26 Households where the income of the main recipient is less than four times the poverty line per household member. The percentages cited are the ratio between the second and third columns of table 8 , multiplied by 100 .
}

education are not paid substantially more even if they have some extra years of schooling. Conversely, incomes increase rapidly for those who have completed the secondary cycle and have some extra years of education on top of this. ${ }^{27}$

Increasingly widespread completion of the secondary education cycle has led to a relative devaluation of education, manifested in the way the earnings of those who have completed this level have progressively fallen behind those of people who have completed higher education, something that can clearly be seen among the young (ECLAC, 2008b). ${ }^{28}$

As increasing numbers of people in the low stratum (manual workers) have achieved higher levels of education and income, and as large segments of the lower middle stratum (non-manual) with complete secondary education have come to be employed for relatively low pay, the incomes of the two strata have tended to converge and earnings have increasingly become dissociated from occupation type.

It is important to realize that, relatively speaking, people completing secondary education now are lowerpaid than those who entered the labour market with this level of qualifications in the past. Completion of secondary education was traditionally the educational threshold for the middle class, as it was understood to confer greater appropriation of the cultural codes of modernity and thus to facilitate access to "intellectual" work. Mass completion of this level was to make it less of a mark of distinction.

Considering the large proportion of young people who have completed secondary education, the glass might be seen as "half full". It might also be seen as "half empty", however, if what is considered instead is the reduced status, both symbolic and material, associated with this attainment. In addition, the standardized tests now applied to measure effective learning and its quality have systematically revealed widespread shortcomings, hastening the symbolic devaluation of the progress made in terms of years of schooling.

Nonetheless, the educational attainments of these new cohorts and the types of job they go into are still highly segmented. In Chile, for example, despite the rapid expansion of education coverage, differences remain in the educational profiles of young people by social category. Over $83 \%$ of those from middlesector families enter the labour market with 12 years

27 See eClaC (2008b, chapter IV, pp. 141-144).

28 This has been a factor in widening pay divides and keeping the inequality of income distribution high in the region. 
of schooling or more, whereas only $43 \%$ of those from working-class families do (León and Martínez, 2007). At the same time, the extraordinary expansion of secondary enrolment during the last decade and the mobility it has brought are striking: $70 \%$ of Chilean university students are the first generation in their families to have studied at this level.

\section{The income divide between manual and non-manual occupations is becoming less clear-cut}

There is a tendency towards homogenization of the incomes earned by middle-class and lower-class individuals. This is because there are many low-grade non-manual jobs, at the same time as there are wellpaid manual occupations. There are "manual workers [who] possess more knowledge than many middle-class workers, earn more and develop clearer aspirations of social mobility. Generally speaking... manual worker status does not preclude eventual membership of the middle class, depending on the industry, the location and the culture of the occupational and social environment. Competitive workers tend to develop expectations, a world view and political demands different to those developed by uncompetitive workers" (Mora y Araujo, 2008).

\section{The penetration of middle-stratum goods and the demonstration effect}

The process described has greatly increased the demand for consumer goods (electrical and electronic products, mobile phones, the Internet, cars, etc.), making the penetration of these goods more "visible". This may have raised their status among people in the low stratum and created a perception that acquiring them is the main route to social integration and not owning them a form of exclusion.

Argentina is a special case. The 2001-2002 crisis resulted in a high level of open unemployment and a decline in family incomes, among other adverse consequences. However, renewed growth from 2003 until well into 2008 meant that, on average, households in the middle and low strata recovered their pre-crisis income levels. In a long-term (point-to-point) comparison, therefore, no marked deterioration is seen in the income of the middle occupational strata. Table 9 summarizes changes in the distribution of households by income bracket in three periods (1990-1999, 1999-2002 and 2002-2006) in Greater Buenos Aires. Between 1999 and 2002 , the percentage of households with annual incomes of less than US\$ 5,000 trebled in the middle occupational stratum and quadrupled in the lower stratum. ${ }^{29}$ The scale of the decline can be seen in the downward shift of all households in the income scale (see the third and sixth columns of table 9). During the recovery, however, income growth benefited low-stratum households more (72\%) than middle-stratum ones (39\%), markedly reducing the income disparity between the two. ${ }^{30}$ This appears to indicate that the middle stratum in Argentina too expanded as a result of the rising consumption capacity of low-stratum households, although this is a more recent phenomenon, as it is in Brazil.

\section{The competitive and the uncompetitive}

Globalization and the interconnectedness of the world economy are affecting the middle classes by giving a crucial role to competitiveness, in the twofold sense of possessing the necessary skills and having the desire to compete and a capacity for risk-taking. The uncompetitive are those whose technological and educational accomplishments are obsolescent and who are therefore ill-prepared for a changing labour market, so that they face the risk of unemployment and a downward drift in wages. Again, insofar as competitiveness involves the incessant renewal of information and knowledge, reskilling and adaptation to new forms of organization, it creates strains and new divisions between losers and winners. All this has undermined a section of the middle class whose specializations or ways of working are less in demand than formerly in the labour market, and particularly those whose age or education level makes it harder for them to adapt. Unionization can help to maintain and even increase pay levels, but its main usefulness is in protecting working conditions and enhancing stability by making it costlier for firms to reduce the number of workers they employ (Mora y Araujo, 2008).

\footnotetext{
${ }^{29}$ It should be recalled that each "occupational stratum" includes all main household income recipients, whether working or inactive.

${ }^{30}$ The average monthly income figures for households in the middle stratum were US\$1,855 in 2002 and US\$2,574 in 2006. The figures for the low stratum were US\$ 1,067 and US\$ 1,835 a month in 2000 dollars at purchasing power parity.
} 
Argentina (Greater Buenos Aires, three periods): distribution of households by family income bracket ${ }^{a}$ and occupational stratum ${ }^{b}$

(Percentages)

\begin{tabular}{|c|c|c|c|c|c|c|}
\hline & Middle stratum & Low stratum & Total & Middle stratum & Low stratum & Total \\
\hline & \multicolumn{3}{|c|}{1990} & \multicolumn{3}{|c|}{1999} \\
\hline Up to 5000 & 5 & 15 & 11 & 5 & 6 & 5 \\
\hline 5001 to 15000 & 33 & 34 & 32 & 28 & 41 & 32 \\
\hline \multirow[t]{2}{*}{ Over 15000} & 63 & 51 & 58 & 67 & 53 & 62 \\
\hline & \multicolumn{3}{|c|}{1999} & \multicolumn{3}{|c|}{2002} \\
\hline Up to 5000 & 5 & 6 & 5 & 16 & 26 & 20 \\
\hline 5001 to 15000 & 28 & 41 & 32 & 39 & 49 & 42 \\
\hline Over 15000 & 67 & 53 & 62 & 46 & 26 & 39 \\
\hline Up to 5000 & 16 & 26 & 20 & 3 & 9 & 6 \\
\hline 5001 to 15000 & 39 & 49 & 42 & 31 & 37 & 32 \\
\hline Over 15000 & 46 & 26 & 39 & 66 & 54 & 62 \\
\hline
\end{tabular}

Source: ECLAC, on the basis of special tabulations of household surveys from the countries concerned.

a The income brackets are for annual income in 2000 dollars at purchasing power parity.

b Some columns do not add up to $100 \%$ because of rounding.

\section{V}

\section{What does it mean to be middle class?}

It is worth reflecting on the differences between the size of the middle class as measured by "objective" criteria and the very much larger number of people self-identifying with that class in demoscopic studies.

\section{The role of consumption in middle-class identity: the euphoric side}

Mass take-up of consumer credit has meant greater access to durable goods and certain services. According to data from ECLAC, the Inter-American Development Bank (IDB) and the World Bank, domestic credit grew from 30\% to $55 \%$ of GDP in the region between 1990 and 2006, with even stronger growth in MERCOSUR (Matesanz and Palma, 2008), and penetration was particularly strong in the middle and low strata. Credit growth in the high sectors matched output growth. The finding overall is that credit grew far faster than output, suggesting that it reached other parts of the population.
The case of Brazil is revealing. Economic growth contributed to the rise in lending operations, which increased tenfold between 1999 and 2007 even as their cost fell. The interest rate, while still very high, dropped from $90.2 \%$ in 1999 to $43.9 \%$ in 2007 . This easier credit strengthened the large consumer market among the poorer classes, and it expanded beyond so-called "class C" households to those in strata D and E, the lowest in the stratification (Oliveira, 2010). ${ }^{31}$

All this has coincided with the advent of the lowcost society (Gaggi and Narduzzi, 2007). A combination of factors has brought in an era of mass consumption: the opening up of international trade, the delocalization

\footnotetext{
31 Groups or strata D and E of the socio-economic classification used in market studies in Brazil comprise the lowest-income households in the stratification scale. The class known as $\mathrm{C}$ is normally identified with the lower middle class, according to the Getulio Vargas Foundation. This now appears to have become the largest class in Brazil thanks to the socio-economic rise of people formerly in classes D and E.
} 
of product and parts manufacturing in pursuit of lowercost factors of production, the rapid spread of new mass production technologies, and scaling up as new consumers have emerged. Electronic items, computers, clothing, package travel, different household items, mobile phones, etc., are all part of an ever larger and more dynamic market of avid consumers and financing.

The combination of greater borrowing capacity (via credit cards) and greater consumption plus the development of large firms oriented towards low-cost mass market products have contributed to the emergence of a new middle class.

Collective identities are now defined and groups distinguished by the symbolic content of consumption, which expresses shared meanings and reinforces the marks of identity and social position. In other words, specific consumers' consumption type provides "signals" that identify them as members of a particular socio-economic stratum. In this context, consumption capacity is central to the formation of middle-class identity and its variability redefines the goods that fulfil the differentiating role associated symbolically with this human activity at any given time (Oliveira, 2010).

Of course, consumption has always played this role as an identifier of lifestyles and as a marker for membership of a social class or group. With the rapid growth of the low-cost society, however, a sophisticated and affluent higher class has tended to be joined by a mass market echelon whose members have medium-low incomes but are able to afford goods and services that were formerly the preserve of higher-income sectors (Gaggi and Narduzzi, 2007). Participation in this new mass consumption tends to be seen and experienced as membership of the middle class.

The fact that everyone is consuming does not mean there is no diversity. There are "consumer profiles" that are mainly associated with age criteria, for example. All this helps to make consumption less homogeneous and create greater freedom for consumers.

This provides an insight into important changes in people's ways of life. In former times, group pressure tended to pigeonhole them by their family, occupational or class relationships. "Late" modernity has increased individualism, as expressed in a greater concern with the self and the opportunity to take up different material and symbolic consumption options. The result is that consumers have fragmented into differentiated groups in accordance with their tastes and affinities, something that has also been instrumental in expanding the market.

This new functioning of society and of individuals' self-perception has enlarged the domain of personal choice, enabling people to mark the differences characteristic of "social closure": the choice of a place of residence and type of housing, the school their children go to, culinary tastes and the places where they choose to satisfy them, places of entertainment and cultural consumption. Studies by Svampa (2001) on life in the so-called "countries" 32 of the upper middle class in Argentina and the later emphasis on the "return to the city" highlighted by Wortman (2010) reveal both this freedom of choice and the way tastes can change in a fairly short space of time. Similarly, Arellano (2008) discusses the emergence in Lima of a new middle class whose origins are in the sierra and which is not "copying" the behaviour of traditional middle-class sectors but is innovating and defining its own lifestyle, in its culinary and musical choices and in other ways.

Of course, not everyone has the same consumption opportunities. There is a sophisticated, affluent higher class with more scope for choice. One might also identify a more established upper middle class with good levels of income and greater opportunities for personalized choices. In contrast, the lower middle class, and its new members in particular, are fulfilling their consumption aspirations in a more standardized way. Nonetheless, a degree of diversity can be found here as well.

\section{The aspiration gap}

People have goals or desires they hope to be able to realize over their lifetimes. In a society characterized by constant renewal, the distance between expectations and attainments is likely to create frustration. Uncompetitive segments of society are subjected to consumerist stimuli that are heightened by rising education levels, urban life and the mass media, but lack the means to satisfy their aspirations and are thus frustrated in their expectations.

There are fields, such as connectivity and interactive long-distance communication, that are expanding particularly among the young. The same is happening in the cultural industries, especially music and audio-visual production and consumption. Falling product prices in these areas have led to greater individualization of the options available to large sections of society, creating the paradox of "mass individualization" (Hopenhayn, 2005, p. 56).

\footnotetext{
32 This is the name given in Argentina and elsewhere to gated communities or condominiums that are usually outside the urban area and have heavy security for their residents, generally people with high or medium-high incomes.
} 
In this context, membership of the middle class is not necessarily determined by people's occupational category or even income, but by their status as consumers in a society where they can afford a wide range of goods that are not standardized but can be selected on the basis

\section{VI}

\section{Conclusions}

The current situation of the middle strata unquestionably presents some novelties. In the period from 1990 to before the 2008 crisis, the number of middle-class households and their average incomes both grew. This resulted from rising GDP in the countries combined with lower poverty and a small improvement in income distribution. Different factors opened the way to these changes. The "short version", taking just the first years of the new century, is that macro factors were largely responsible, in the form of improved financing facilities for the region's countries and strong demand for many of their exportable products. The "long version" is that slow-acting developmental transformations have taken place, such as the decline in the family dependency rate and faster incorporation of women into the labour market, together with the benefits of the "demographic dividend" (i.e., the increase in the number of income recipients per household relative to the number of dependants). This has coincided with the so-called "low-cost society", characterized by the emergence of industries which set out to bring down the unit cost of many "symbolic" consumer goods formerly affordable only for higher-income strata and by the increased availability of credit at lower interest rates for people on low incomes, contributing to a dynamic of upward social mobility.

The two-dimensional definition of the middle class used in this study brings to light the incorporation into the middle class of households from the manual occupational stratum as their incomes (and thence their consumption) have increased because of the economic growth of the past 16 years. Even without significant improvements in income distribution, the substantial absolute growth in per capita GDP between the beginning of the last decade and the middle of the present one allowed consumption to rise in middle- and lower-stratum households in several countries. There was a "shift" in the household income distribution towards higher income brackets. This was very significant for social stratification, even if it is not perceptible in analyses of income distribution of particular preferences. People aspire to participate in this new consumer realm, and this is identified with being middle class. Ergo, there does not necessarily have to be a correlation between objective conditions and subjective perceptions. across household deciles or quintiles. It all helped to increase demand for consumer goods that came into increasingly widespread use (electrical and electronic products, mobile phones, Internet access, cars, etc.) and rendered more "visible" the penetration of such goods among large sections of the population. In these changes lies one of the clues to the greater heterogeneity of the middle strata in terms of occupation type, place of residence and opportunities for different lifestyles, resulting in turn in a greater homogeneity in the goods that can be afforded by those "incorporated" into the middle stratum by way of rising incomes and access to consumption, the latter having been expanded by the remarkable growth in credit.

This study set out by recognizing that the position of individuals in the labour market is no longer sufficient to describe the social structure and delimit its intermediate strata, as the character of occupations has changed and other aspects have become more important, such as consumption and lifestyles. From an occupational perspective, the size of the middle stratum differed substantially by countries' development level, but increased in all of them except one where it fell slightly and one where it held steady. The rise in the absolute number of middle-stratum households (56 million, taking the total to 128 million households in 16 years) gives a better idea of the remarkable demonstration effect generated by certain increasingly widespread consumption patterns. In the two countries with the largest populations (Brazil and Mexico), the numbers increased by 28 million and 14 million households, respectively.

There were major changes in household size and composition that account for the expansion of the middle strata over the past 15 years. Lower fertility and dependency rates allowed more women to go out to work, and the net result was to increase family incomes and consumption opportunities in the middle and lower strata. 
In most of the countries, the lower middle sector accounts for between two thirds and over three quarters of all middle-stratum households. Furthermore, a large proportion of wage earners in this sector work under poor conditions, with very low incomes and often without a contract or social security coverage. The analysis of "horizontal" segmentation in the middle stratum does not support either the hypothesis of a diminishing role for the State as an employer or the hypothesis of rising self-employment and a matching reduction in wage employment in the private sector.

Although there are now greater opportunities for educational attainment, a complete secondary education has been devalued in terms of the employment and earning opportunities it commands. The educational attainments of people in the lower stratum have been rising and large sections of the lower middle stratum have complete secondary education, and this has led to homogenization of incomes between the two strata and to occupation type becoming decoupled from income.

Lastly, it is important to emphasize the structural changes undergone by the region's societies in the period analysed, especially those deriving from the remarkable development of international trade, including the emergence of new actors with a huge capacity for producing manufactured goods for export while providing a large source of demand for products of every kind. This has led to major changes in social stratification in the countries analysed, and these have been manifested particularly strongly in alterations in the size and characteristics of the middle classes.

(Original: Spanish)

\section{Bibliography}

Arellano, Rolando (2008), Valores e ideología: el comportamiento político y económico de las nuevas clases medias en América Latina, Barcelona, Economic Commission for Latin America and the Caribbean (ECLAC)/Centro de Información y Documentación de Barcelona (СIDOB).

Birdsall, Nancy, Carol Graham and S. Pettinato (2000), "Stuck in the tunnel: is globalization muddling the middle class?", Working Paper, No. 14, Washington, D.C., Center on Social and Economic Dynamics, The Brookings Institution, August.

ECLAC (Economic Commission for Latin America and the Caribbean) (2008a), Social Panorama of Latin America, 2008 (LC/G.2402-P), Santiago, Chile, December. United Nations publication, Sales No. E.08.II.G.89.

(2008b), Juventud y cohesión social en Iberoamérica: un modelo para armar (LC/G.2391), Santiago, Chile, Economic Commission for Latin America and the Caribbean/Spanish Agency for International Cooperation/Ibero-American Secretariat/Ibero-American Youth Organization, Santiago, Chile, October.

(2007), Social Panorama of Latin America, 2007 (LC/G.2351-P), Santiago, Chile. United Nations publication, Sales No. E.07.II.G.124.

(2004), Social Panorama of Latina America, 2004 (LC/G.2259-P), Santiago, Chile. United Nations publication, Sales No. E.04.II.G.148.

ECLAC/ILO (Economic Commission for Latin America and the Caribbean/International Labour Organization) (2009), "Crisis and the labour market", ECLAC/ILO Bulletin, No. 1, Santiago, Chile, June.

Escobar Latapí, Agustín and Laura Pedraza (2010), "Clases medias en México: transformación social, sujetos múltiples”, Clases medias en América Latina. Retrospectiva y cambios recientes, Rolando Franco, Martín Hopenhayn and Arturo León, Mexico City, ECLAC/Ibero-American Secretariat/Siglo XXI editores.

Espinoza, Vicente (2009), "Entrevista”, ¿Cómo han cambiado la o las clases medias durante los últimos 20 años?, Santiago, Chile, Expansiva, May.
Franco, Rolando and Martín Hopenhayn (2010), "Las clases medias en América Latina: historias cruzadas y miradas diversas", Clases medias en América Latina. Retrospectiva y cambios recientes, Rolando Franco, Martín Hopenhayn and Arturo León, Mexico City, ECLAC/Ibero-American Secretariat/Siglo XXI editores.

Franco, Rolando, Martín Hopenhayn and Arturo León (2010), Clases medias en América Latina. Retrospectiva y cambios recientes, Mexico City, ECLAC/Ibero-American Secretariat/ Siglo XXI editores.

Franco, Rolando, Arturo León and Raúl Atria (2007), Estratificación y movilidad social en América Latina. Transformaciones estructurales de un cuarto de siglo, Santiago, Chile, Economic Commission for Latin America and the Caribbean (CEPAL)/ LOM ediciones.

Gaggi, Massimo and Edoardo Narduzzi (2007), El fin de la clase media y el nacimiento de la sociedad de bajo coste, Madrid, Editorial Lengua de Trapo.

Hopenhayn, Martín (2005), América Latina desigual y descentrada, Buenos Aires, Editorial Norma.

Kessler, Gabriel and Vicente Espinoza (2007), "Movilidad social y trayectorias ocupacionales en Buenos Aires. Continuidades, rupturas y paradojas", Estratificación y movilidad social en América Latina. Transformaciones estructurales de un cuarto de siglo, Rolando Franco, Arturo León and Raúl Atria, Santiago, Chile, Economic Commission for Latin America and the Caribbean (ECLAC)/LOM ediciones.

Klein, Emilio and Víctor Tokman (2000), "Social stratification under tension in a globalized era", CEPAL Review, No. 72 (LC/G.2120-P), Santiago, Chile, Economic Commission for Latin America and the Caribbean (ECLAC), December.

León, Arturo, Ernesto Espíndola and Camilo Sembler (2010), "Clases medias en América Latina: una visión de sus cambios en las dos últimas décadas", Clases medias en América Latina. Retrospectiva y cambios recientes, Rolando Franco, Martín Hopenhayn and Arturo León, Mexico City, ECLAC/IberoAmerican Secretariat/Siglo XXI editores. 
León, Arturo and Javier Martínez (2007), "La estratificación social en Chile hacia fines del siglo XX", Estratificación y movilidad social en América Latina. Transformaciones estructurales de un cuarto de siglo, Rolando Franco, Arturo León and Raúl Atria, Santiago, Chile, Economic Commission for Latin America and the Caribbean (ECLAC)/LOM ediciones.

Matesanz, David and Andrés Palma (2008), Las clases medias latinoamericanas y España: oportunidades y desafíos, Madrid, Observatorio de Política Exterior Española (OPEX)-Fundación Alternativas.

Méndez, María Luisa (2010), "Clases medias en Chile: transformaciones, sentido de pertenencia y tensiones entre proyectos de movilidad", Clases medias en América Latina. Retrospectiva y cambios recientes, Rolando Franco, Martín Hopenhayn and Arturo León, Mexico City, ECLAC/IberoAmerican Secretariat/Siglo XXI editores.

(2009), "Entrevista", ¿Cómo han cambiado la o las clases medias durante los últimos 20 años?, Santiago, Chile, Expansiva, May.

Méndez, María Luisa and Modesto Gayo (2007), "El perfil de un debate: movilidad y meritocracia. Contribución al estudio de las sociedades latinoamericanas", Estratificación y movilidad social en América Latina. Transformaciones estructurales de un cuarto de siglo, Rolando Franco, Arturo León and Raúl Atria, Santiago, Chile, Economic Commission for Latin America and the Caribbean (ECLAC)/LOM ediciones.

Mora y Araujo, Manuel (2008), Vulnerabilidad de las clases medias en América Latina. Competitividad individual y posición social, Barcelona, Economic Commission for Latin America and the Caribbean (ECLAC)/Centro de Información y Documentación de Barcelona (СIDOB).

(2007), "La estructura social de la Argentina: evidencias y conjeturas acerca de la estratificación actual", Estratificación y movilidad social en América Latina. Transformaciones estructurales de un cuarto de siglo, Rolando Franco, Arturo León and Raúl Atria, Santiago, Chile, Economic Commission for Latin America and the Caribbean (ECLAC)/ LOM ediciones.
Oliveira, Fabiana Luci de (2010), "Movilidad social y económica en el Brasil. ¿Una nueva clase media?", Clases medias en América Latina. Retrospectiva y cambios recientes, Rolando Franco, Martín Hopenhayn and Arturo León, Mexico City, ECLAC/ Ibero-American Secretariat/Siglo XXI editores.

Pessoa de Carvalho Filho, Eneuton Dornellas (2002), "Evolução do emprego no Brasil nos anos 60", thesis, Campinas, State University at Campinas.

Solimano, Andrés (2008), "The middle class and the development process", Macroeconomía del desarrollo series, No. 65 (LC/ L.2892-P), Santiago, Chile, Economic Commission for Latin America and the Caribbean (ECLAC), April. United Nations publication, Sales No. E.08.II.G.29.

Svampa, Maristella (2001), Los que ganaron, la vida en countries y barrios privados, Buenos Aires, Editorial Biblos.

Toche, Eduardo (2010), "Aproximaciones a la clase media de Lima", Clases medias en América Latina. Retrospectiva y cambios recientes, Rolando Franco, Martín Hopenhayn and Arturo León, Mexico City, ECLAC/Ibero-American Secretariat/Siglo XXI editores.

Torche, Florencia (2006), "Una clasificación de clases para la sociedad chilena", Revista de sociología, No. 20, Santiago, Chile, Faculty of Social Sciences, University of Chile.

Torche, Florencia and Guillermo Wormald (2007), "Chile, entre la adscripción y el logro", Estratificación y movilidad social en América Latina. Transformaciones estructurales de un cuarto de siglo, Rolando Franco, Arturo León and Raúl Atria, Santiago, Chile, Economic Commission for Latin America and the Caribbean (ECLAC)/LOM ediciones.

Wilson, Dominic and Raluca Dragusanu (2008), The Expanding Middle: the Exploding World Middle Class and Falling Global Inequality, New York, Goldman Sachs, July.

World Bank (2006), World Development Report 2006: Equity and Development, Washington, D.C.

Wortman, Ana (2010), "Las clases medias argentinas", Clases medias en América Latina. Retrospectiva y cambios recientes, Rolando Franco, Martín Hopenhayn and Arturo León, Mexico City, ECLAC/Ibero-American Secretariat/Siglo XXI editores. 